\title{
THE TISSUE REACTION IN THE LUNGS OF RATS AFTER THE INHALATION OF COAL DUST CONTAINING $2 \%$ OF QUARTZ
}

BY

\author{
E. J. KING, S. ZAIDI, C. V. HARRISON, and G. NAGELSCHMIDT \\ From the Postgraduate Medical School of London and the Safety in Mines Research Establishment, Sheffield
}

(RECEIVED FOR PUBLICATION JULY 30, 1957)

Belt and King (1945) found that pure coal dust, whether anthracite or bituminous, was of low pathogenicity, producing only minimal fibrosis; but there was some evidence to show that with increased siliceous matter in the coal the pathogenicity also increased. King, Harrison, and Ray (1949) found that when 5 and $10 \mathrm{mg}$. of quartz were mixed with 95 and $90 \mathrm{mg}$. of anthracite coal respectively and injected intratracheally into rats larger and more numerous nodules containing more reticulin resulted than were produced by the injections of clean coal (anthracite with very little ash). Ray, King, and Harrison (1951a) showed that when $2 \mathrm{mg}$. of quartz was given by intratracheal injection to rats there was no fibrotic reaction in the animals' lungs since it was removed to the hilar lymph nodes, where it did cause some fibrosis. Pure anthracite $(100 \mathrm{mg}$.), when introduced into the lungs by the same route, also produced no pulmonary fibrosis, but when $2 \mathrm{mg}$. quartz was mixed with $98 \mathrm{mg}$. of pure anthracite coal and injected into the lungs, fibrotic nodules resulted. Ray et al. (1951b) realized the limitation of their experiment in that the intratracheal technique did not simulate dust inhalation. Hence, they suggested the repetition of the experiments by a dusting technique.

The present work was undertaken to find out whether a small amount of silica mixed with pure anthracite coal would lead to pulmonary fibrosis. Two dusting experiments were set up, the first with a light exposure to quartz alone and the second with a mixture of $2 \%$ quartz and $98 \%$ coal.

\section{Methods and Materials}

Quartz.-The powdered quartz was the same preparation as that used for the interlaboratory analytical trials (Nagelschmidt, 1956). All particles in this dust were under $10 \mu$ (Table 1).

Anthracite Coal Dust.-The anthracite coal was obtained by Dr. B. M. Wright (Pneumoconiosis Research
TABLE 1

PARTICLE SIZE DISTRIBUTION OF POWDERED QUARTZ AND ANTHRACITE COAL

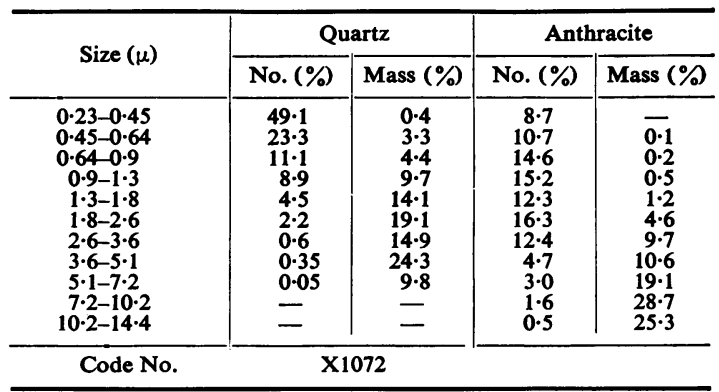

Unit, Cardiff) from a South Wales mine. Its ash content was $2.4 \%$, mainly kaolin, with some haematite and no quartz. By chemical analysis about one-third of the ash was silica (from kaolin). It was ground in a " turbine grinder" (Wright, 1953) and then separated, using a Roller apparatus, into a fine fraction for dusting. All particles were under $14 \mu ; 99 \%$ (by number) and $75 \%$ by mass were under $10 \mu$ (Table 1).

Mixture of $98 \%$ Anthracite Coal and $2 \%$ Quartz.-An intimate mixture of $2 \%$ quartz (by weight) with $98 \%$ anthracite coal was prepared. Thorough mixing was ensured by grinding overnight in an electrically driven mortar. The airborne dust produced in the dusting cabinet from this mixture was sampled in London by the thermal precipitator and counted in Sheffield by the normal microscopic method used for evaluation of thermal precipitator samples, namely, an oil-immersion $2 \mathrm{~mm}$. objective, a 17-fold eyepiece, and the sample mounted in air. A graticule with a $\sqrt{2}$ progression was used instead of the Patterson graticule. The mass distributions of coal and quartz were calculated from the counts (Cartwright, 1956). The distinction between coal and quartz was uncertain below $0.5 \mu$, but the resulting error is negligible for the mass proportions of coal and quartz. The counts showed all of the dust to be under $10 \mu$ (Table 1a). In a representative sample total counts 
TABLE 1a

COMPOSITION OF DUST CLOUD PRODUCED FROM MIXTURE OF $98 \%$ ANTHRACITE COAL WITH $2 \%$ QUARTZ

\begin{tabular}{|c|c|c|c|c|}
\hline \multirow{2}{*}{ Size $(\mu)$} & \multicolumn{2}{|c|}{ Coal } & \multicolumn{2}{|c|}{ Quartz } \\
\hline & No. $(\%)$ & Mass (\%) & No. $(\%)$ & Mass (\%) \\
\hline $\begin{array}{l}0.23-0.32 \\
0.32-0.45 \\
0.45-0.64 \\
0.64-0.9 \\
0.9-1.3 \\
1.3-1.3 \\
1.8-2.6 \\
2.6-3.6 \\
3.6-5.6 \\
5.1-7.2 \\
7.2-10.2\end{array}$ & $\begin{array}{r}5.0 \\
10.5 \\
7.0 \\
11.3 \\
19.6 \\
22.0 \\
16.2 \\
6.0 \\
1.6 \\
0.7 \\
0.1\end{array}$ & $\begin{array}{l}\overline{-} \\
0.1 \\
0.6 \\
3.2 \\
10.0 \\
20.5 \\
21.9 \\
16.5 \\
20.0 \\
7.2\end{array}$ & $\begin{array}{r}\overline{0.7} \\
8.6 \\
25.7 \\
20.0 \\
22.2 \\
15.7 \\
5.0 \\
2.1 \\
=\end{array}$ & $\begin{array}{l}\bar{Z} \\
\overline{0.2} \\
2 \cdot 0 \\
4 \cdot 3 \\
13 \cdot 4 \\
27 \cdot 0 \\
24 \cdot 3 \\
28.8 \\
=\end{array}$ \\
\hline $\begin{array}{l}\mathbf{M}^{*} \\
\mathbf{M}^{*}\end{array}$ & \multicolumn{2}{|c|}{$\begin{array}{l}3.2 \\
1.7\end{array}$} & \multicolumn{2}{|c|}{$\begin{array}{l}2 \cdot 3 \\
1.7\end{array}$} \\
\hline
\end{tabular}

*MMD = mass median diameter: size at $50 \%$ mass on cumulative size distribution curve.

${ }^{*} \sigma=$ geometrical standard deviation: mean of ratios of diameters having $50 \%$ and $16.5 \%$ mass or having $83.5 \%$ and $50 \%$ mass.

of 612 coal particles and 140 quartz particles were made by counting quartz in $\mathbf{1 5}$ times the area used for the coal counts. The size distributions of coal and quartz were very similar (Table 1a). The calculated quartz percentage by mass was $2 \cdot 1 \%$. The mass median diameter (M.M.D) for coal was 3.2 $\mu$, and for quartz the M.M.D. was $2 \cdot 3 \mu$.

Dusting Cabinets. - The animals were placed in specially designed cabinets (King, Wright, Ray, and Harrison, 1950), in which the concentration of dust could be regulated (Wright, 1953). The overall dust concentrations (all particles under $10 \mu$ ) were determined by means of the thermal precipitator (Green and Watson, 1935), daily in the initial stages of the experiment and monthly as a check-up, and it was found that, having arranged conditions to produce a required dust cloud, the concentration remained reasonably constant over the course of the experiment. Size distributions of the airborne dusts are given in Table 1a for the mixed dust and in Table $1 \mathrm{~b}$ for the quartz.

TABLE 1b

SIZE DISTRIBUTION OF DUST CLOUD PRODUCED FROM QUARTZ

\begin{tabular}{c|c|c}
\hline Size $(\mu)$ & No. $(\%)$ & Mass (\%) \\
\cline { 2 - 3 } $0.23-0.32$ & 23.2 & 0.2 \\
$0.32-0.45$ & 24.0 & 0.5 \\
$0.45-0.64$ & 9.3 & 0.5 \\
0.640 .9 & 10.5 & 1.6 \\
$0.9-1.3$ & 11.4 & 5.0 \\
$1.3-1.8$ & 11.4 & 13.9 \\
$1.8-2.6$ & 6.7 & 22.6 \\
$2.6-3.6$ & 2.7 & 26.4 \\
$3.6-5.1$ & 0.7 & 18.7 \\
$5.1-7.2$ & 0.1 & 10.6 \\
\hline Code No. & X1072 \\
\hline
\end{tabular}

Animals

The rats were of the black and white hooded variety of the Medical Research Council strain. They were males and their average weight was $150 \mathrm{~g}$. Two groups of 30 animals were used in the quartz and the coal $+2 \%$ quartz experiments.

\section{Dusting and Duration of the Experiments}

The animals in the coal + quartz group were dusted on an average for 11 hours a day, five days a week, except for holidays and breakdowns. Because only half the rats could be accommodated at a time, and for convenience, this was done by exposing half the animals for five hours in the day and the other half for 17 hours overnight, changing over the animals once a week. After 330 days dusting was discontinued, and 14 animals kept for a further 110 days. Throughout the experiment the concentration of dust in the coal + quartz cabinet was maintained at 20,000 particles $(0 \cdot 2$ to $10 \mu)$ per millilitre of air. Based on the differential counts, this gave about 300 particles of quartz in the 20,000 particles of mixture per millilitre of air. The 20,000 particles for 11 hours corresponds to $20,000 \times 11=220,000$ " particle hours" of dusting per day, the 300 of quartz to 3,300 " particle hours".

The rats in the quartz group were dusted for 90 minutes per day for five days per week with a dust cloud of 3,000 particles of quartz per millilitre of air, the lowest concentration which could be adjusted. The quartz dust exposure of 90 minutes (1.5 hour) with 3,000 particles per $\mathrm{ml}$. was taken to correspond to $3,000 \times 1 \cdot 5=4,500$ "particle hours" of dusting per day. Dusting was continued for $\mathbf{3 9 0}$ days, and 13 animals were kept for a further 110 days. The total " particle hours" of dusting, deaths, and killings are shown in Table 2.

TABLE 2

SURVIVAL TIMES AND “ PARTICLE HOURS” OF DUSTING

\begin{tabular}{|c|c|c|}
\hline $\begin{array}{l}\text { Days of } \\
\text { Survival }\end{array}$ & $\begin{array}{c}\text { Quartz Alone } \\
\text { (m. "particle hours") }\end{array}$ & $\begin{array}{l}\text { Coal }+2 \% \text { Quartz } \\
\text { (m. "particle hours") }\end{array}$ \\
\hline $\begin{array}{r}30 \\
60 \\
120 \\
180 \\
210 \\
240 \\
270 \\
280 \\
300 \\
330\end{array}$ & $\begin{array}{c}\overline{-} \\
K(2) 0.30 \\
K(2) 0.45 \\
K(2) 0.65 \\
K(2) 0.74 \\
K(2) 0.85 \\
K(2) 0.94\end{array}$ & $\begin{array}{l}D^{*}(1) 7.96 \\
K(2) 17.8 \\
K(2) \quad 27.4 \\
K(2) 32.2 \\
K(2) 37.3 \\
K(2) \quad 41.7 \\
D(1) \quad 42.8 \\
K(2) 45.4 \\
K(2) 49.4\end{array}$ \\
\hline $\begin{array}{l}360 \\
390 \\
440 \\
500\end{array}$ & $\begin{array}{l}D(1) 1 \cdot 01 \\
K(2) 1 \cdot 02 \\
K(2) 1 \cdot 12 \\
K(13) 1 \cdot 12\end{array}$ & $\bar{Z}_{\mathbf{Z}(1 \overline{4})}{ }^{49 \cdot 4}$ \\
\hline
\end{tabular}

$* \mathbf{K}=$ killed and $\mathbf{D}=$ died. Numbers in brackets refer to numbers of rats killed or dead.

At the end of the dusting periods the surviving animals had been dusted as follows: quartz rats for 1 million particle hours; coal $+2 \%$ quartz rats for 49 million particle hours, which included 0.75 million quartz particle hours, i.e., 49 million $\times 300 / 20,000$.

\section{Pathological Technique}

Routine necropsies were carried out on all rats. The trachea was tied off, the thoracic cavity opened, and the lungs, with the tied-off portion of trachea, were removed and placed in $10 \%$ formol saline. Blocks were selected along the long axes of both the lungs at the level of the hilum to include the maximum representative area from each lung. The tracheo-bronchial glands were also fixed 
in $10 \%$ formol saline. The fixation was completed in fresh fixative. The blocks of the lungs and tracheobronchial glands were embedded in paraffin separately and sections cut at $5 \mu$.

\section{Chemical Analyses}

The lungs and tracheo-bronchial lymph nodes of eight rats killed at $\mathbf{4 4 0}$ days from the coal $+2 \%$ quartz group and the lungs and lymph nodes of six rats killed at 500 days in the quartz group were dried overnight at $105^{\circ} \mathrm{C}$., and each rat's lungs and lymph nodes were ground to a fine powder. The powder obtained from each pair of lungs and nodes in the coal $+2 \%$ quartz group was divided into two roughly equal parts; one was used for coal estimation (King and Gilchrist, 1945) and the other for chemical estimation of silica (King, Stacy, Holt, Yates, and Pickles, 1955). Suitable amounts of the powders obtained from the lungs and nodes of each of the rats in the quartz group were analysed for silica.

\section{Results}

Pathological Findings.-The rats dusted with quartz alone, even though they were dusted for a period of 500 days, did not show dust foci or macroscopic fibrosis either in the lungs or lymph nodes. The concentration of dust particles and the time of dusting (4,500 particle hours per day) were apparently insufficient to produce silicosis.

In the group inhaling the mixture of coal dust and quartz the rat which died at 60 days showed minute dust foci situated mainly on the dorsal aspect and free margins of the lungs. In the case of the rats killed at 120 days, dust accumulation in the lungs was characterized by the presence of dust foci, larger than those seen at 60 days, situated on both the pleural and cut surfaces of the lungs and separated by unpigmented lung tissue. During the remaining period of the experiment the dust foci were seen gradually to increase in size, but their distribution appeared to be more or less constant. The rats killed at 330 and 440 days showed dust foc, $i$ about 1 to $2 \mathrm{~mm}$. in diameter.

The most marked macroscopic changes were to be seen in the tracheo-bronchial lymph nodes. At 60 days the nodes were slightly enlarged and a few discrete groups of accumulated coal dust were seen in them. At 120 days they. were still larger and covered with heavy deposits of coal which obscured the normal lymphoid tissue. At $\mathbf{3 3 0}$ days the nodes were about three times their normal size and at 440 days they were completely filled with coal dust.

Microscopic Appearances.-Histologically the lungs and lymph nodes of the rats dusted with quartz alone did not show any evidence of fibrosis. A few doubly refractile particles could be seen in tiny subpleural drifts, and in macrophages scattered throughout the lung, at all stages of dusting. In the lymph nodes, they were collected together in very small foci, in which only a few reticulin fibres were seen.

The lungs of the rat dusted with coal $+2 \%$ quartz for 60 days showed that most of the dust was engulfed by macrophages which were scattered throughout the lungs. A very few free coal particles were also seen. At $\mathbf{1 2 0}$ days the dust-laden macrophages were seen to lie singly or grouped into small foci (Fig. 1). The outlines of the macrophages in some places were obscured by the compact masses of coal, and many of the alveolar walls appeared thickened due to cellular swelling and proliferation. From this period onwards up to 300 days the dust collections became more compact, and at these sites the alveolar septa were obliterated. At 330 days there were definite circumscribed foci of coal dust throughout the lungs (Fig. 3). They gradually increased in size, and at $\mathbf{4 4 0}$ days were fairly large, but there was no evidence of fibrosis.

In sections of the lymph nodes at 60 days macrophages were seen, laden with coal dust, and at 120 days were seen to form nodular masses situated mostly at the periphery and in between the lymphoid follicles of the lymph nodes (Fig. 2). As the hours of dust exposure were increased, more and more dust accumulated in the lymph nodes, and at $\mathbf{4 4 0}$ days they were loaded with irregular clumps of coal dust (Fig. 4).

Gordon and Sweets' (1936) silver impregnation of the lungs showed no increase of reticulin in the lungs of any of the animals dusted with coal + $2 \%$ quartz. The lymph nodes of the rats in this group showed the presence of a few thin reticulin fibres around the dust foci at $\mathbf{3 3 0}$ days, and more and thicker reticulin fibres were seen amidst the dust foci in the lymph nodes at $\mathbf{4 4 0}$ days.

Silica and Coal Content of Lungs.-In six rats dusted with quartz and killed at $\mathbf{5 0 0}$ days the total silica present varied from $0.24 \mathrm{mg}$. to $0.35 \mathrm{mg}$., mean value $0.31 \mathrm{mg}$. (Table 3 ). This was a much lower content than had been expected.

In eight rats dusted with $98 \%$ coal and $2 \%$ quartz and killed at 440 days the total amount of coal present varied from $23.5 \mathrm{mg}$. to $72.5 \mathrm{mg}$., mean value $42.9 \mathrm{mg}$. The total silica present varied from $1 \mathrm{mg}$. to $3.28 \mathrm{mg}$., mean value $2.02 \mathrm{mg}$. Silica derived from the kaolin in the coal ranged from $0.19 \mathrm{mg}$. to $0.58 \mathrm{mg}$., mean $0.34 \mathrm{mg}$. After deducting these values from the total silicas, the values of silica from quartz ranged from $0.79 \mathrm{mg}$. to $2.76 \mathrm{mg}$, mean value $1.68 \mathrm{mg}$. The mean quartz percentage of the lung dust was $3 \cdot 7$, suggesting some preferential inhalation or retention of quartz. 

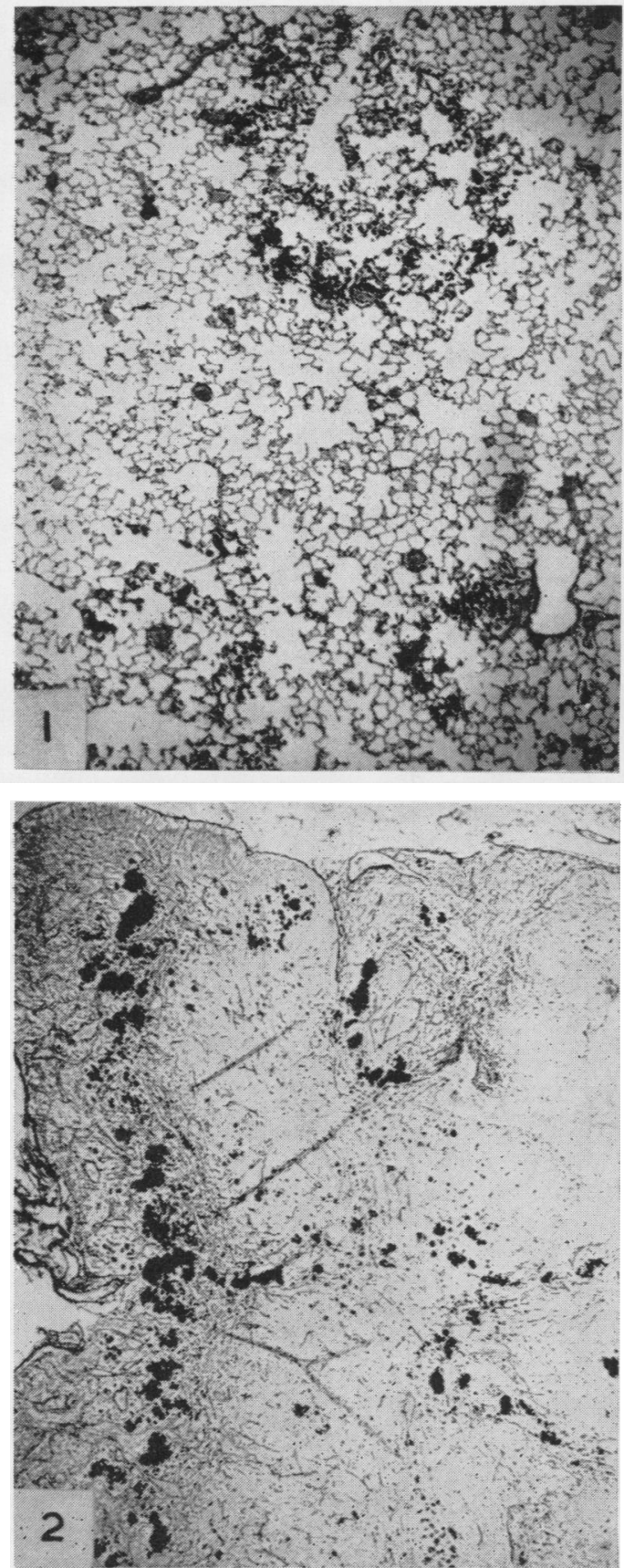

Fig. 1.-Rat lung, dusted 120 days (17.8 million " particle hours") with a mixture of anthracite dust $98 \%$ and quartz $2 \%$. Macrophages laden with coal dust in alveoli and collections of dust in small compact masses. Haematoxylin and eosin, $\times 50$.

Fig. 2.-Tracheo-bronchial lymph node from same rat as in Fig. 1. Dust seen in periphery and between germinal centres; lymph sinuses patent; no fibrosis. Haematoxylin and eosin, $\times 50$.
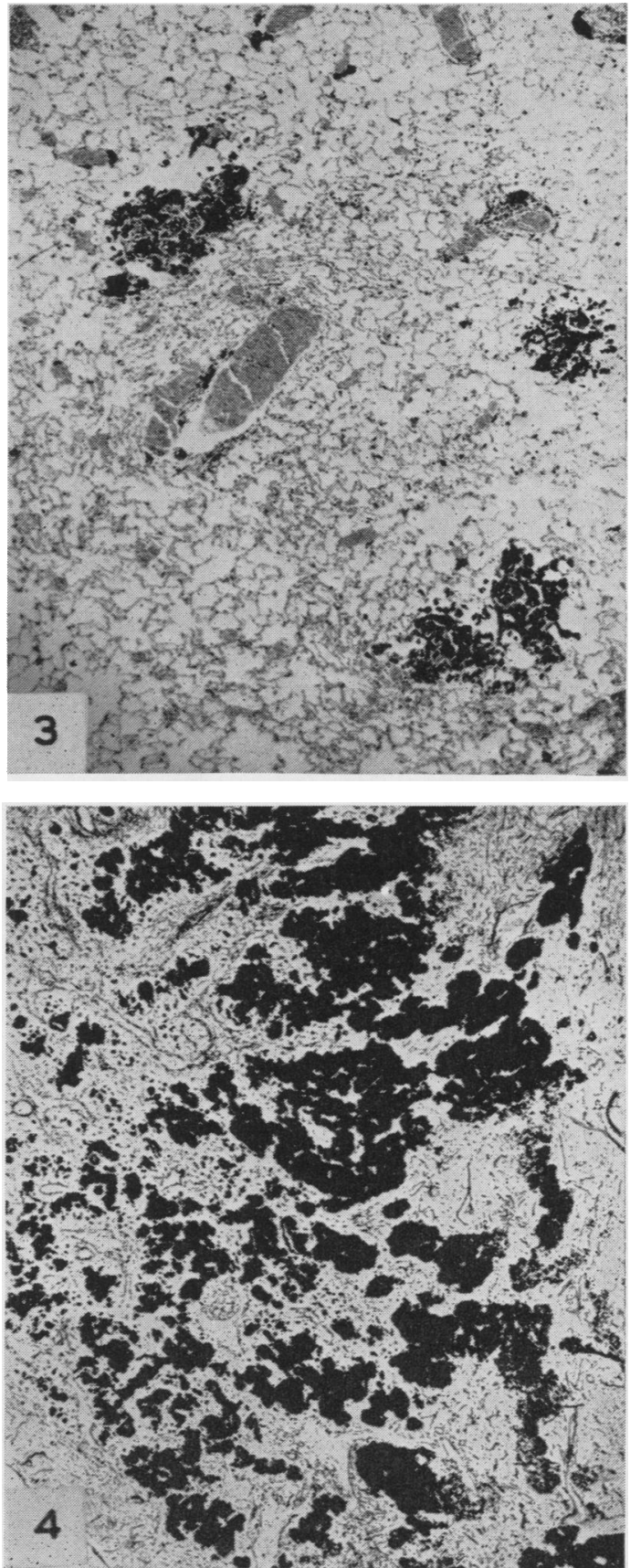

Fig. 3.-Rat lung, dusted 330 days (49.4 million " particle hours") with a mixture of anthracite dust $98 \%$ and quartz $2 \%$ and killed 110 days after the cessation of dusting. Dust collected in definite foci. Very few reticulin fibres. Haematoxylin and eosin, $\times 50$

Fig. 4. -Tracheo-bronchial lymph node from same rat as in Fig. 3. Dust present in large masses which are tending to fuse together. Very few reticulin fibres. Haematoxylin and eosin, $\times 50$. 
ANALYSES OF LUNGS AND LYMPH NODES FROM RATS DUSTED WITH QUARTZ AND WITH MIXTURE OF ANTHRACITE COAL (98\%) AND QUARTZ (2\%)

\begin{tabular}{|c|c|c|c|c|c|c|}
\hline $\begin{array}{l}\text { Dry Weight of Lungs } \\
\text { and Lymph Nodes } \\
\text { (g.) }\end{array}$ & $\begin{array}{l}\text { Coal in Lungs } \\
\text { and Lymph Nodes } \\
(\%)\end{array}$ & $\begin{array}{l}\mathrm{SiO}_{2} \text { in Lungs } \\
\text { and } \mathrm{Lymph}_{(\%)} \text { Nodes }\end{array}$ & $\begin{array}{l}\text { Total Coal } \\
\text { Present } \\
\text { (mg.) }\end{array}$ & $\begin{array}{c}\text { Total SiO, } \\
\text { Present } \\
\text { (mg.) }\end{array}$ & $\begin{array}{c}\mathrm{SiO}_{2} \text { from Siliceous } \\
\text { Matter *from Coal } \\
\text { (mg.) }\end{array}$ & $\begin{array}{l}\text { Silica from } \\
\text { Quartz† } \\
\text { (mg.) }\end{array}$ \\
\hline $\begin{array}{c}\text { Dusted with Coal }+ \\
1.086 \\
1.161 \\
0.754 \\
1.014 \\
0.811 \\
0.727 \\
1.029 \\
0.816\end{array}$ & $\begin{array}{c}2 \% \text { Quartz (killed at } \\
3.75 \\
5.61 \\
3.12 \\
2.86 \\
3.65 \\
7.73 \\
7.05 \\
3.25\end{array}$ & $\begin{array}{r}140 \text { days) } \\
0.16 \\
0 \cdot 28 \\
0 \cdot 21 \\
0 \cdot 22 \\
0 \cdot 15 \\
0 \cdot 32 \\
0 \cdot 27 \\
0 \cdot 12\end{array}$ & $\begin{array}{l}40 \cdot 7 \\
65 \cdot 2 \\
23 \cdot 5 \\
29 \cdot 5 \\
29 \cdot 6 \\
56 \cdot 2 \\
72 \cdot 5 \\
26 \cdot 5\end{array}$ & $\begin{array}{l}1 \cdot 73 \\
3 \cdot 28 \\
1 \cdot 57 \\
2 \cdot 22 \\
1 \cdot 23 \\
2 \cdot 30 \\
2 \cdot 80 \\
1 \cdot 00\end{array}$ & $\begin{array}{l}0.33 \\
0.52 \\
0.19 \\
0.23 \\
0.24 \\
0.45 \\
0.58 \\
0.21\end{array}$ & $\begin{array}{l}1 \cdot 40 \\
2 \cdot 76 \\
1 \cdot 38 \\
1.99 \\
0.99 \\
1 \cdot 85 \\
2 \cdot 22 \\
0.79\end{array}$ \\
\hline Mean Values 0.927 & $4 \cdot 62$ & 0.22 & $42 \cdot 9$ & $2 \cdot 02$ & 0.34 & 1.68 \\
\hline $\begin{array}{cl}\text { Dusted with Quartz } \\
0.711 \\
0.709 \\
0.457 \\
0.838 \\
0.779 \\
0.396\end{array}$ & $\begin{array}{c}\text { (killed at } 500 \text { days) } \\
= \\
= \\
= \\
-\end{array}$ & $\begin{array}{l}0.04 \\
0.05 \\
0.07 \\
0.04 \\
0.03 \\
0.08\end{array}$ & $\begin{array}{l}E \\
z \\
z\end{array}$ & $\begin{array}{l}0.28 \\
0 \cdot 35 \\
0.32 \\
0.34 \\
0.24 \\
0.32\end{array}$ & $\begin{array}{l}- \\
z \\
-\end{array}$ & $\begin{array}{l}E \\
E \\
-\end{array}$ \\
\hline Mean Values 0.648 & - & 0.06 & 一 & 0.31 & - & - \\
\hline
\end{tabular}

* Calculated from the silica content of anthracite coal $(2.4 \% \times 1 / 3=0.8 \%)$.

+ By difference.

\section{Discussion}

The inhalation of anthracite coal dust with small amounts $(2 \%)$ of quartz over prolonged periods led to the development of dust foci, scattered throughout the lungs, without any fibrosis. The accumulations of dust were in the alveoli, respiratory bronchioles, and alveolar ducts. These findings are similar to those of Heppleston (1954) in the lungs of rabbits inhaling coal dust underground; but, unlike Heppleston's rabbits, our rats did not develop any marked focal emphysema. Gross (1931) noted thickening of the alveolar walls without any fibroblastic changes in the lungs of rabbits dusted with coal dust, which closely resembles the findings of these experiments. Badham (1940) concluded that prolonged dusting of rabbits and guinea-pigs with coal dust does not cause pulmonary fibrosis.

Heppleston (1954) found that relatively little dust entered the lymphatic system of rabbits exposed to coal dust; but in our experiment the tracheobronchial lymph nodes of the rats dusted with anthracite coal dust and quartz showed nodular masses of dust when the dust-laden macrophages were still lying singly or grouped in small foci in the lungs. At all times there appeared to be a much higher concentration of dust in the lymph nodes than in the lungs. These findings support the views of Willis (1921) and Gardner (1940), who were of the opinion that it is only after the hilar glands have become choked with dust that a parenchymal accumulation begins, gradually extending from the hilar region towards the periphery of the lung.

Because Ray et al. (1951a, b) had found some fibrosis to result when $2 \mathrm{mg}$. of quartz with $98 \mathrm{mg}$. of coal was intratracheally injected into rats, we were surprised at the comparative absence of pulmonary fibrosis in the present experiments. In the intratracheal injection method the whole of the dust is introduced in one dose and acts in the lung from the beginning; about half of it is permanently retained (Nagelschmidt, Nelson, King, Attygalle, and Yoganathan, 1957). After 440 days' dusting in the present experiment, only $1.68 \mathrm{mg}$. (on the average) of quartz was found in the lungs and lymph nodes. There is no evidence of the rate at which the quartz accumulated, but during most of the experimental periods there must have been much less than these amounts present. We had not, in fact, achieved in these dusting experiments sufficiently high concentrations of quartz in the lungs, nor had the amounts retained been there long enough to produce more than a mild reticulinosis in the lymph nodes, despite the simultaneous presence of considerable amounts (30 to $70 \mathrm{mg}$.) of coal.

Rats dusted with a dust cloud of 3,000 particles of quartz per millilitre of air for 1.5 hours per day over a period of about 400 days (1.12 million "particle hours'" dusting) did not show any evidence of fibrosis in the lungs or lymph nodes.

The chemical analyses of the lungs and lymph nodes of rats dusted with the mixture of coal and $2 \%$ quartz showed variable amounts of coal and silica. The mean silica from quartz value $(1.68 \mathrm{mg}$. per rat) was five times higher than the silica found in the lungs and lymph nodes of the rats dusted with quartz alone $(0.31 \mathrm{mg}$. per rat), although the mixed dust group had had a lower total exposure to quartz, i.e., 0.75 as against 1.1 million " particle hours". This finding suggests that small amounts of dust are got rid of without causing any damage 
to the lungs or lymph nodes. When they contain large amounts of coal, the lungs may not be able so readily to rid themselves of small amounts of quartz.

It is interesting to compare the dosage and retention of dust observed with recent data given by Wright (1957), who used a gravimetric thermal precipitator and found, after 18 months of dusting with coal (100 hours per week, experiment $3 \mathrm{~A})$, an average value of $97 \mathrm{mg}$. per rat which corresponded to $22 \%$ retention of the dust inhaled.

A rough calculation of the total weight below $7 \mu$ given to our mixed dust group, using the same rat minute value of $100 \mathrm{ml}$. as taken by Wright, gives a total intake of $1,000 \mathrm{mg}$. or a recovery of only $4.4 \%$. But as our cloud must have been about six times as concentrated as that used by Wright there may have been more aggregation and consequently less uptake into the lungs. Furthermore, Wright's rats were killed and analysed immediately after the end of the dust exposure, whereas ours survived without dusting for another 110 days and may have eliminated some dust. It would be desirable, in future experiments, to measure the dust dosage simultaneously by gravimetric and counting techniques in order to establish accurately the pattern of the relationship between dust exposure and retention, in lungs and lymph nodes, of inert and fibrogenic dusts and their mixtures.

\section{Summary}

Rats were dusted, over a period of 500 days, with (1) a low concentration of quartz, and (2) a high concentration of anthracite coal dust containing $2 \%$ of added quartz.

There was no fibrosis produced in the lungs or lymph nodes of animals dusted with the low concentration of quartz alone. The amounts of silica found by analysis in these rats were much less than those in the mixture of anthracite and $2 \%$ quartz rats, despite the " quartz particle hours " of dusting being roughly similar.

In the rats dusted with the mixture of $98 \%$ anthracite and $2 \%$ quartz, discrete dust foci developed in the lungs and lymph nodes, without showing any evidence of fibrosis in the lungs and only a little in the lymph nodes.

Our thanks are due to the Medical Research Council and the National Coal Board for grants to cover the expenses of this investigation, and to Mr. B. S. C. Hollands for technical assistance.

\section{REFERENCES}

Badham, C. (1940). Silicosis: Proc. int. Conf., Geneva, pp. 24, 81. I.L.O. Studies and Reports, Series $F$, No. 17. Geneva.

Belt, T. H., and King E. J. (1945). Spec. Rep. Ser. med. Res. Coun. (Lond.), No. 250, p. 29

Cartwright, J. (1956). Safety in Mines Research Establishment Research Report No. 128. Sheffield, Ministry of Fuel and Power.

Gardner, L. U. (1940). J. Amer. med. Ass., 114, 535.

Gordon, H., and Sweets, H. H. (1936). Amer. J. Path., 12, 545.

Green, H. L., and Watson, H. H. (1935). Spec. Rep. Ser. med. Res. Coun. (Lond.), No. 199

Gross, H. (1931). Mschr. Unfallheilk, 38, 151

Heppleston, A. G. (1954). J. Path. Bact., 67, 349.

King, E. J., and Gilchrist, M. (1945). Spec. Rep. Ser, med. Res.

Coun. (Lond.), No. 250, p. 21. (1949). Proc 9th Int Cong. industr. Med. Lond. 1948, p. 666. Wright, Bristol.

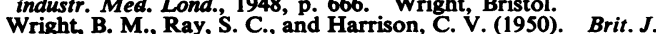
Wright, B. M., Ray,

industr. Med., 7, 27.
Stacy, B. D., Holt, P. F., Yates, D. M., and Pickles, D. (1955).

Analyst, 80, 441.
Nagelschmidt, G. (1956). Ibid., 81, 210.

Nelson, E. S., King, E. J., Attygalle, D., and Yoganathan, M. (1957). A.M.A. Arch. industr. Hlth, 16, 188.

Ray, S. C., King, E. J., and Harrison, C. V. (1951a). Brit. J. industr. Med., 8, 62.

Willis, H, (1951b). Ibid., 8, 68.

Wright,

Wrigh, B. Mrit. industr. Med 14., $\mathrm{p}_{\mathrm{ig}} 8$. 